2018-09

\title{
Sustainable eating: Opportunities for nutrition professionals
}

\author{
Pettinger, Clare
}

http://hdl.handle.net/10026.1/11783

10.1111/nbu. 12335

Nutrition Bulletin

Wiley

All content in PEARL is protected by copyright law. Author manuscripts are made available in accordance with publisher policies. Please cite only the published version using the details provided on the item record or document. In the absence of an open licence (e.g. Creative Commons), permissions for further reuse of content should be sought from the publisher or author. 
Sustainable Eating: Opportunities for Nutrition Professionals

C. Pettinger

Correspondence: Dr Clare Pettinger, Lecturer Public Health Dietetics, SF15, Peninsula Allied Health Centre (PAHC) School of Health Professionals, University of Plymouth, UK PL6 8BH

\begin{abstract}
Increasing demand for food from a growing human population is leading to adverse environmental and health consequences. The emerging topical issue of sustainable eating and diets might offer new opportunities for the training of nutrition professionals. Ongoing research is uncovering synergies between how dietary patterns can meet both health and environmental goals. Yet this area is a challenge for the nutrition professions, as relevant education often involves politically driven, systems-leadership style thinking, which is drawn from a less familiar evidence base than traditional nutritional sciences. As pressures mount to achieve sustainability agenda goals, new evidence appraisal and educational input are essential to support the potential role of nutrition professionals. This article appraises sustainable eating and diets, as well as considering the value of better education to be embedded more consistently within nutrition curricula and Continued Professional Development (CPD), to achieve sustainability literacy for nutrition professionals. The importance of stronger advocacy skills and collaborative leadership is also highlighted, as well as the need for more effective high-level policy involvement. Recommendations for how nutrition professionals can be more effectively equipped for this emerging and dynamic area of professional practice are provided.
\end{abstract}

Keywords: Sustainable eating and diets; nutrition professionals; education for sustainability; nutrition curricula; collaborative leadership for sustainability

\title{
Acknowledgements and declaration of interest
}

The author declares no conflict of interest relating to this review article which was made possible via a University of Plymouth Pedagogic Teaching, Research and Innovation (PTRI) funding award. With support from Wendy Miller, Harriet Dismore, Lynne Wyness, Elizabeth Atherton and dietetic and nutrition students. Thanks also to the British Dietetic Association 
and Association for Nutrition and my nutrition and dietetic colleagues working to promote sustainability. 


\section{Introduction}

The current food system is unsustainable and 'distorted by inequalities of access' (Lang 2015). More than enough food is generated for the 7 billion population, yet half the global population is malnourished (FAO 2015) and about 2 billion are deficient in key micronutrients (FAO 2014). The consequent 'double burden' of disease (obesity and malnutrition), partially driven by 'the nutrition transition' (Popkin 2002) to increased dietary intakes of refined sugars, fats, oils and processed meats, is related to a pandemic of illhealth, which in the UK costs the NHS $f 6$ billion each year (BMA 2016; Fitzpatrick \& Young 2017). If unchecked, it is predicted that by 2050 current dietary trends will cause significant damage to the environment (e.g. biodiversity loss and increased pollution), as well as increased ill health (i.e. higher prevalence of chronic non-communicable disease). The implementation of solutions to address the tightly linked 'diet-environment-health' trilemma is, therefore, a pressing global challenge (Tilman \& Clark 2014).

There is increasing food demand for the growing human population, from an already challenged food system that is stressed by the degradation of global ecosystems (Frey \& Barrett 2007). Globally, food production accounts for around a quarter of all Greenhouse Gas Emissions (GHGe) (Vermeulen et al. 2012), the majority of which result from the rearing of livestock for meat, dairy and eggs, which generate $18 \%-20 \%$ of total GHGe (Green et al. 2015). Animal agriculture and industrial agriculture are clear drivers of unsustainable climate change (FAO 2006; UNEP 2016). The UK has a target to reduce GHGe by $80 \%$ from 1990 levels by 2050 (UK Government 2008). Government has also recognised the pressure on the availability of water for use in agriculture and the need to reduce this impact (DEFRA 2006). Optimising land use for food production, such as reducing the amount of land required for the rearing of meat, would have a positive environmental impact in a range of ways. In order to achieve climate change-related targets, and mitigate the harsh effects of climate change, agriculture and food production methods need to change, as well as dietary intake patterns (Bajzelj et al. 2014; MacDiarmid et al. 2012).

In general, the UK population does not currently consume the right balance of food recommended for either a healthy or a sustainable diet (Harland et al. 2012). The UK National Diet and Nutrition Survey continues to report high consumption of free sugars, salt 
and saturated fat and low intake of fruit and vegetables (PHE 2016). An 'unhealthy' dietary pattern is strongly associated with, and causally linked with, a number of chronic, complex conditions, such as obesity, cardiovascular disease, some cancers and type 2 diabetes (BMA 2016). It is suggested that a more sustainable diet can be achieved by reducing meat (red and processed meat in particular) and dairy products in the diet, and replacing these with appropriate plant-based proteins, such as beans and pulses, and plant-based dairy alternatives; an eating pattern that aligns with recommendations in the Eatwell Guide (PHE 2016). There is growing evidence of the link between the consumption of large amounts of red and processed meat and poor health outcomes (Cross et al. 2007; Kontogianni et al. 2008)). This may be related to the high saturated fat content of animal products, high salt levels in processed meats and to the displacement of fruit and vegetables and cereals by high meat consumption (Scarborough et al. 2012). There are, of course, important nutritional implications for meat reduction, such as potential mineral (e.g. iron or zinc) depletion (Millward \& Garnett 2010), highlighting the need for nutrition professionals in advising on dietary changes.

'Sustainable eating' is known to be a broad and complex issue, which lies at the intersection of public health, environmental health and the business of food (Garnett 2014; Lang \& Barling 2013). Food is a massive industry and the many key players involved have differing interests (Tansey 2015). There is a call for stronger multi-sector leadership in championing a sustainable ecological approach to the food system (Food Research Collaboration 2014). There is opportunity for nutrition professionals to be part of this discourse, but are they equipped for this role?

\section{Nutrition professionals and sustainability}

Relatively little has been written specifically about the potential role of nutrition professionals in pushing the sustainability agenda. This is surprising given they are educated in competencies around the therapeutic use of food, nutritional adequacy, health improvement and healthy eating (BDA 2014; AfN 2018) and that environmental perspectives are increasingly influencing debates around healthy eating (Lang \& Barling 2013; PHE 2016). With global pressures mounting to achieve the Sustainable Development Goals (UN SDG, 2016), which seek a more prominent role for food and nutrition (UN 2014), 
research in the US has highlighted the enabling factors, such as self-efficacy, for dietitians to embed sustainability in their professional practice (Hawkins et al. 2015). In the UK, however, there is relatively little recognition or support for the emerging role for dietitians or nutritionists in promoting sustainable eating. In a recently updated Sustainable Diet policy statement, the British Dietetic Association (BDA) commented that the profession should be leading discussions on how food behaviours can affect both health and the environment (BDA 2017) and that dietitians are in a strong position to combine healthy eating messages and sustainable dietary advice. However, educational learning and curricula have yet to change to reflect this. UK dietetics and nutrition curricula are formed around standards of education and training for professional competency achievement (BDA 2013; AfN 2016; AfN 2017) based largely on the biomedical model of health. The UN Global Action Plan for Sustainable Development (Fischer et al. 2015) has recognised students as important potential change agents within their professions. Fischer et al. (2015) recommend that sustainability practices should be integrated into education through whole institution approaches, with students as active participants in the process. A major challenge is to embed this emerging topic throughout the nutrition profession curricula.

As academic registered dietitian Erickson-Weerts (1999) stated, 'staying viable requires shifting from medical models and mentality and therapeutic diets to public health arenas, policy and wellness'. The Giessen Declaration in 2005 highlighted how 'new nutrition science' needed to move beyond biomedical science to address ethical concerns that include social and ecological factors (Beauman et al. 2005) and proposed more problemsolving scientific approaches coupled with compassion, socio-economics and a planetary perspective (Wahlqvist 2005). The Giessen Declaration states that an integrative approach with strong technology links is needed to address human security (Beauman et al. 2005). This proposed change in thinking is already being embraced by some - for example, The Critical Dietetics movement 'seeks to explore new ways of framing how we educate, practice and research in dietetics (i.e. the professional discipline of nutrition)' (Gingras et al. 2014). This type of change needs to be embraced more widely as nutrition professionals of the future are likely to have a key role in translating less familiar forms of scientific evidence (e.g. climate science; political science) to incorporate sustainability principles within their professional practice. Despite some apparent basic 'tokenistic' mentions of sustainability 
within current curriculum frameworks [mainly seen within competencies covering themes such as 'food chain' and 'health/wellbeing' (BDA 2013; AfN 2016; 2017)], there needs to be more effective integration of a range of elements relating to the breadth and depth of the sustainable diets discourse.

\section{Understanding sustainable diets}

There are complexities surrounding definitional aspects of sustainable diets and a lack of one single clear definition (Atherton 2016; Mason \& Lang 2017). The best-known global definition of a sustainable diet is 'those diets with low environmental impacts which contribute to food and nutrition security and to healthy life for present and future generations. Sustainable diets are protective and respectful of biodiversity and ecosystems, culturally acceptable, accessible, economically fair and affordable; nutritionally adequate, safe and healthy; while optimising natural and human resources' (Burlingame \& Dernini 2010).

This definition appears comprehensive and was created by an international committee, as part of a 'Biodiversity and Sustainable Diets' symposium hosted in 2010 by FAO, but can be challenging to interpret. It includes human welfare criteria, as well as environmental/ecological factors. Yet, these interlinking concepts are complex and some seem contradictory, even rival in nature (Arens 2014) as they pose great ethical and moral challenges. Translation of what a sustainable diet looks like 'on a plate' is, therefore, difficult, even for nutrition professionals. Until recently there was little evidence about whether a sustainable diet could in practice also be healthy. A study by MacDiarmid et al. (2012) assessed whether a reduction in GHGEs can be achieved while meeting dietary requirements for health. They concluded that it is possible without eliminating meat or dairy products or even increasing the cost to the consumer. However, GHGEs is only one environmental aspect of sustainable eating and so the recommendation was for future research to explore how food choices impact on other elements such as water use and waste. An extensive discussion paper by Garnett (2014) argues that a sustainable and healthy diet is possible, and that low environmental impact dietary patterns can be consistent with good health and dietary recommendations (see box 1 ). 
Box 1 . The key characteristics of a sustainable and healthy diet. Reproduced with permission (Gonzales-Fischer \& Garnett 2016)

- Diversity - eat a wide variety of foods

- Balance - achieved between energy intake and energy needs

- Minimally processed foods (including plenty of wholegrains, legumes, fruit and vegetables)

- Meat, if eaten, in moderate quantities

- Dairy products (or alternatives) also in moderation

- Unsalted seeds and nuts

- Small quantities of fish and aquatic products (sourced from certified fisheries)

- Limit consumption of foods high in fat, sugars or salt

- Choose oils and fats wisely (opt for rapeseed and olive)

- Tap water in preference to other beverages

Globally, over the past several years, dietary guidelines have been emerging that incorporate aspects of sustainability to varying degrees. Qatar, for example, produced one of the first national dietary guidelines to integrate principles of food sustainability (Seed 2015). Similarly, Sweden and Brazil have taken radical steps to embed sustainability and social drivers and determinants into their national dietary guidelines [National Food Agency (Sweden) 2015; Ministry of Health for Brazil 2014].

In the UK, the latest healthy eating model, the Eatwell Guide, was introduced in 2016, to replace the Eatwell Plate, putting more emphasis on plant-based foods, suggesting lower intakes of meat-based proteins and mentioning 'sustainably sourced' fish (PHE 2016). This is in addition to continuing to recommend diets high in fruit and vegetables and wholegrain carbohydrates, and low in saturated fat, free sugars and salt. Analysis by the Carbon Trust concluded that the dietary pattern recommended by the Eatwell Guide now 'shows an appreciably lower environmental impact than the current UK diet' (Carbon Trust 2016). 
Dietary modelling studies have confirmed that the largest improvements in terms of both improving public health and reducing the impact of climate change (and water and land use) are gained by reducing consumption of red and processed meat (Aston et al. 2012; Riley \& Buttriss 2011) and reduction in dairy consumption (Scarborough et al. 2012). Garton (2017) provides a comprehensive and practical outline of the opportunities for nutrition professionals to support consumers to engage more effectively in a shift towards a more sustainable diet (Table 1).

Table 1. Drivers for change and opportunities for shifting towards a more sustainable diet - the Role for Nutrition Professionals. Adapted with permission (Garton 2017).

\begin{tabular}{|c|c|c|}
\hline Driver & Opportunity & Role for Nutrition Professional \\
\hline Habits & $\begin{array}{l}\text { Non-meat or lower meat } \\
\text { choices to be good value, } \\
\text { accessible and desirable tasty } \\
\text { choices }\end{array}$ & $\begin{array}{l}\text { Provide practical advice, such as } \\
\text { meat free recipes, recipes including } \\
\text { more plant protein, how to increase } \\
\text { intake of fruit, vegetables and } \\
\text { wholegrains }\end{array}$ \\
\hline $\begin{array}{l}\text { Cultural } \\
\text { significance of } \\
\text { meat eating }\end{array}$ & $\begin{array}{l}\text { Draw on traditional diets } \\
\text { based on lower meat and } \\
\text { plant-based eating }\end{array}$ & $\begin{array}{l}\text { Educate on different types of plant- } \\
\text { based diets (e.g. Mediterranean diet, } \\
\text { Asian and Middle Eastern cuisine) }\end{array}$ \\
\hline Price/cost & $\begin{array}{l}\text { Lower meat diets can save } \\
\text { money and enable 'better' } \\
\text { meat choices within the same } \\
\text { budget }\end{array}$ & $\begin{array}{l}\text { Educate and provide practical } \\
\text { suggestions to minimise waste and } \\
\text { save money; for example, advice on } \\
\text { how to use leftovers, portion sizes, } \\
\text { seasonal fruit and vegetables etc. }\end{array}$ \\
\hline Interest in Health & $\begin{array}{l}\text { Promotion of strong public } \\
\text { health messages }\end{array}$ & $\begin{array}{l}\text { Highlight benefits of healthy eating; } \\
\text { practical advice to ensure nutritional } \\
\text { adequacy; bust nutritional myths } \\
\text { (e.g. protein and iron adequacy) }\end{array}$ \\
\hline
\end{tabular}




\begin{tabular}{|c|c|c|}
\hline $\begin{array}{l}\text { Awareness of the } \\
\text { environmental } \\
\text { impact }\end{array}$ & $\begin{array}{l}\text { Awareness raising campaigns, } \\
\text { information, education and } \\
\text { better labelling (where } \\
\text { appropriate) }\end{array}$ & $\begin{array}{l}\text { Provide information and educate on } \\
\text { the role of the food system on the } \\
\text { environment; reconcile the } \\
\text { nutritional and environmental } \\
\text { science to give consistent messages } \\
\text { about a healthy, sustainable diet }\end{array}$ \\
\hline $\begin{array}{l}\text { Knowledge about } \\
\text { alternatives to } \\
\text { meat and dairy }\end{array}$ & $\begin{array}{l}\text { Growth in meat- and dairy- } \\
\text { alternatives market provides } \\
\text { opportunities for consumers } \\
\text { to transition to a more plant- } \\
\text { based diet }\end{array}$ & $\begin{array}{l}\text { Advise on suitable alternatives to } \\
\text { ensure nutritional adequacy }\end{array}$ \\
\hline
\end{tabular}

There appears to be a good understanding of the broad conceptual definitions of sustainable eating amongst UK dietitians (Pettinger \& Atherton 2017). Even so, a small sample of student dietitians reported that they do not have the confidence in their knowledge to apply it effectively (Pettinger et al. 2018). This small scale exploratory research with (student) dietitians and minimal available data for UK (student) nutritionists, suggests a need for more research in this area. There is a need for consensus on the definition of a sustainable diet, supported by the possibility of the introduction of professional standards in the area (Mason \& Lang 2017). As well as improving education, skills and extending the remit of evidence-based based practice, these actions might allow sustainability to form a stronger part of dietetic and nutrition curricula, so that associated values can be translated and embedded within nutrition professional practice.

\section{Sustainable food choices -a quandary for consumers?}

Previous experiences, gender, socioeconomic status and global food supply patterns are just some of the factors that can influence food choices (Caraher \& Coveney 2004). Consumers are also influenced by nutrition and health messages from a range of different sources, some of them conflicting (Webb \& Bryd-Bredbenner 2015). The sustainable diet agenda is likely to add to the plethora of messaging, and potentially confuse consumers further (Mason \& Lang, 2017). This presents opportunity for nutrition professionals as their skills 
will be increasingly needed to help consumers make both sustainable and healthy food choices.

There are suggestions that individuals who are more concerned about food sustainability (e.g. ethical beliefs, environmental concerns and local production) have a healthier diet (Alles et al. 2017). On the other hand, there is evidence that the nutritional quality of a diet does not necessarily equate to how sustainable it is (Vieux et al. 2013). In terms of economics, the influence of socioeconomic status on food choice and dietary behaviours is well-established (Cummins et al. 2010; Darmon \& Drewnowski 2008; UK DEFRA 2011) and it is known that low income and area deprivations are barriers to purchasing healthier foods in the UK (Marmot 2010). Disadvantaged groups are also known to experience the greatest inequality in affordability of a healthy and sustainable diet (in a study which used a hypothetical 'healthy and sustainable' food basket) (Barosh et al. 2014).

The lack of consensus on what constitutes a sustainable dietary pattern is likely to be a barrier to encouraging consumers to make sustainable food choices. One study of adults from 842 households in Nottinghamshire (UK) (Clonan et al. 2012) found that consumers gave 'health' reasons more frequently than it was 'sustainably sourced' for purchasing fish, although the respondents did not meet the recommended intake of fish set by The Department of Health. A similar conflict was identified in a subsequent paper on meat, whereby consumers were more likely to be motivated by 'health' and 'animal welfare issues' for avoiding red and processed meat than 'environmental sustainability' (Clonan et al. 2015). A study conducted by the Eating Better Alliance explored public awareness of the environmental impact of food and their willingness to reduce meat consumption and identified opportunities to shift towards a more sustainable diet (Dibb \& Fitzpatrick 2014). The most promising drivers for change were reported to include 'concern for health', 'farm animal welfare' and 'cost savings' (all of which were rated higher than 'environment') and the barriers included 'habitual behaviours' and 'cultural/personal significance of meat eating'. Nutrition professionals need to be able to reconcile some of these contradictions (see Table 1), to support consumers, regardless of their socio-demographic position and knowledge around sustainability, in their attempt to engage in healthy and sustainable eating practices. 


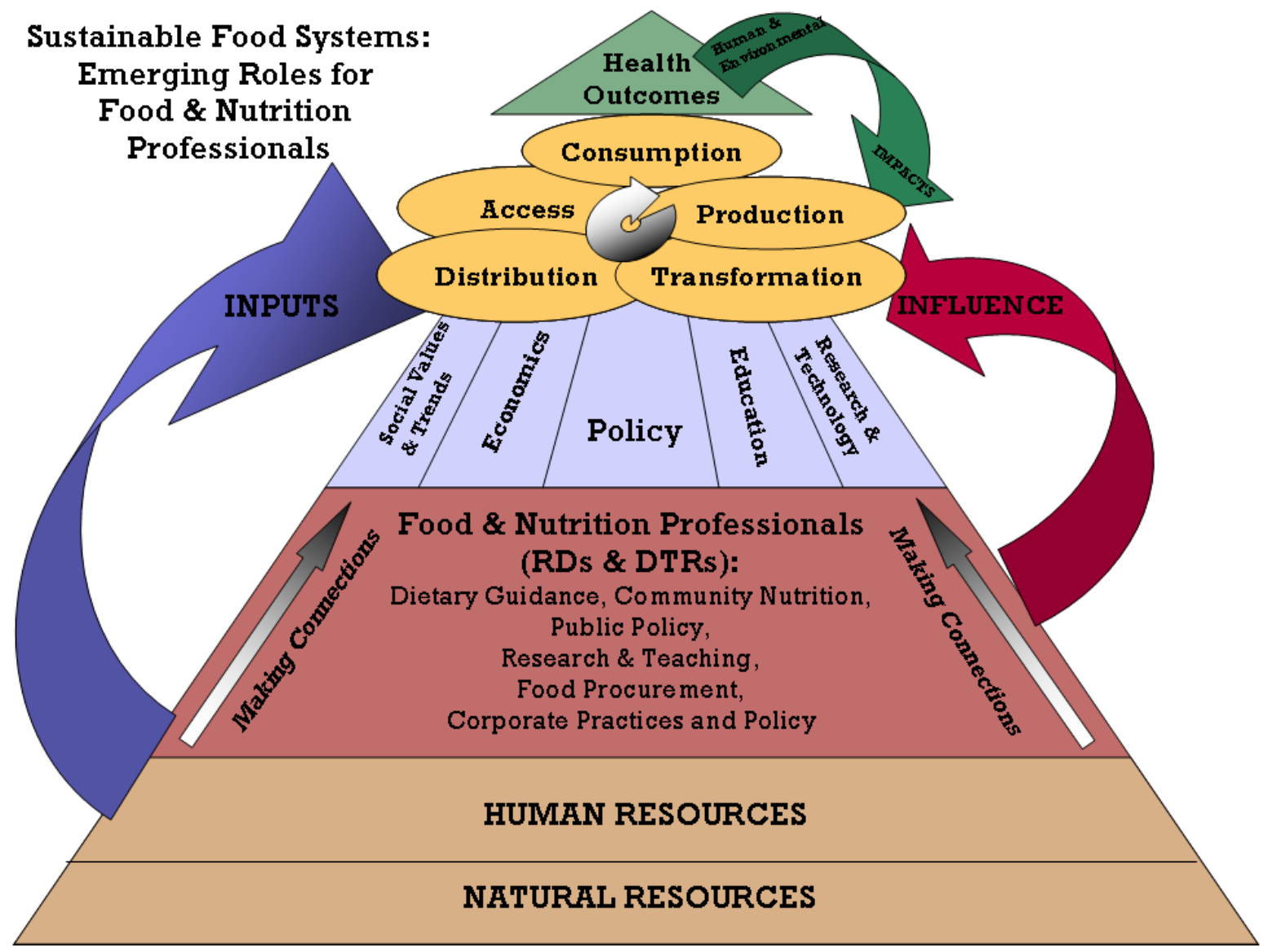

Figure 1. The role of nutrition professionals in Supporting Sustainable Food Systems in the US. Reproduced with permission (Tagtow and Harmon 2009). Registered Dietitians (RD) and Dietetic Technician Registered (DTR).

\section{Education for sustainability}

It is known that being a university student in the UK is associated with increased commitment to environmental sustainability (Cotton \& Alcock 2013), and that universities are potential sites for transformation around sustainable education (Winter et al. 2015). However, there seem to be certain behavioural and attitudinal assumptions made that link higher education to sustainability and global citizenship (Shepherd et al. 2014). David Orr (2004) has been frequently cited for attributing environmental problems to education itself, stating, for example, 'it is not education, but education of a certain kind that will save us' (Orr 2004 p8). With education for sustainability increasingly seen as an important issue in higher education (Cotton \& Alcock 2013), it has been suggested that 'all learners should acquire the knowledge and skills needed to promote sustainable development' (UN, SDG 2016). 
Despite the widely acknowledged importance of education for sustainable development (ESD) (Sterling 2012) and a more sustainable healthcare sector, there is limited literature on ESD for healthcare professions. Goodman (2011) argues a need for a 'sustainability curriculum' for nurses, yet minimal work has been done relating to dietetic and nutrition curricula. In a recent exploratory pedagogic study by Pettinger et al. (2018), dietetic students $(n=18)$ within a participatory workshop, agreed that education on sustainability should 'be throughout every subject'. Earlier work by Harmon et al. (2011) explored the quality and quantity of teaching about food systems and sustainability for dietetic students in the US. The authors reported inadequate time in the curriculum as being the most significant perceived barrier to expanding teaching on the food system and sustainability (Dawe et al. 2005). More research is needed that includes dietetic and other nutrition students.

The education and training of nutrition practitioners should prepare individuals to diversify their professional role throughout their career. Figure 1 highlights some examples of 'extended' roles within the nutrition profession, which are becoming established in the US (RD and DTR are American roles). This is particularly important in the UK as recent NHS bursary reform (Department of Health 2017) has reduced the number of applicants for dietetic courses in England. With the expectation that this transitional phase might provide new opportunities for dietitians (Hickson et al. 2017) and nutritionists, there is a need to create innovative 'Unique Selling Points' (USP) for all nutrition and dietetic programmes in the UK. An educational curriculum for dietetic and nutrition students that emphasises 'sustainability literacy' might be one such USP. This could be achieved with student led sustainability focused scenario-based approaches to learning (Richardson et al. 2017) that involves co-learning with students from other disciplines (e.g. climate science; political science). Such workshops could be embedded within already existing problem-based learning activities (Du et al. 2013). Innes and colleagues (2016) looked at the integration of 'environmental literacy' in undergraduate nutrition programs in the US and found that a 2week food sustainability module improved students' sustainable literacy levels. This 


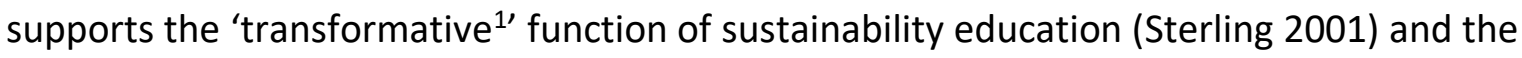
need to use a 'sustainability lens' through which to view the development of curricula that are fit for the future (Goodman \& East 2014). Despite the need for better education in sustainability, there is some wariness in higher education about promoting such transformational learning beyond the student's professional sphere because, it is thought, students are more likely to have their transformative experiences outside of the formal curriculum (Winter et al. 2015). This is where Continued Professional Development (CPD) plays an important role.

More knowledge about sustainable diets is required for nutrition professionals to integrate this topic more consistently into professional practice (Heidelberger et al. 2017) and students have reported a strong desire to learn more on this topic (Pettinger et al. 2018). Learning for all health care professionals is life-long, a commitment to which is shown through CPD activities. For professional practitioners, there is scope to 'self-educate' by attending sustainability related CPD courses, such as webinars (e.g. Garton 2016; Pettinger \& Atherton 2017) and for those practitioners with existing skills to design and deliver appropriate practical CPD activities (e.g. 'how to' guides and 'toolkits' to support learning across the profession). As indicated above, other forms of CPD (outside the formal education setting) need to be considered. The growing wave of active local food networks, for example, might provide nutrition students with the opportunity for experiential learning. Such networks can help to tackle food justice and inequalities (Miller 2015), although more evidence is needed to support this type of role in education.

The BDA in the UK is currently developing a 'sustainable diets' toolkit for dietitians (BDA 2017), but professional bodies in the US and Canada seem to be doing more to promote sustainable food systems at the strategic level (Wegener 2018; Carlsson 2017). The UK may learn from approaches taken in the US, which have included the publication of the 'Standards for Professional Performance for Registered Dietitian Nutritionist in Sustainable, Resilient, and Healthy Food and Water Systems' (Tagtow et al 2014). Education for sustainability needs to be more firmly embedded in nutrition programmes in the UK, to fulfil

\footnotetext{
${ }^{1}$ Transformative learning is a pedagogic approach that promises the depth of learning appropriate to the scale of change that many argue is necessary (Orr, 2004, Sterling 2001)
} 
the recommendations set out in the UK Education for Sustainable Development Guidelines (QAA/HEA Education for Sustainable Development group 2014) and align these with recent Allied Health Profession public health curricula design guidance (Council of Deans 2017). Dietitians (and nutritionists) have an important role in addressing the many challenges of building a more resilient and sustainable food system (see Figure 1, Tagtow \& Harmon 2009). Harmon (2011) has highlighted the need to develop foundational educational knowledge and skill competencies for nutrition professionals related to food systems and sustainability and it has been described as an obligatory 'professional growth area' by Wegener (2018).

\section{Advocacy for sustainability}

The notion of health advocacy is perhaps most developed within Public Health frameworks, where health policy and advocacy are clear objectives of the Faculty of Public Health in the UK (Faculty of Public Health 2010). Sustainability advocacy relates to wider complex food system issues, pertaining to environment, society and economy, and strategic priorities now need to be clearly set for nutrition professionals (Carlsson et al. 2017). Some of these complex issues have been simplified by Mason and Lang $(2017, \mathrm{p} 21)$. Overall, it is agreed that nutrition professionals need to embrace with urgency not only the 'sustainable diet' agenda but also align this within the wider health vs. 'eco-system' contexts (Lang 2018). Furthermore, the need for sustainability advocacy to be 'people-centred' and grow via 'collective agency' is outlined in a recent toolkit produced by the International Institute for Environment and Development (IIED \& HIVOS 2018). Nutrition professionals have an important role to play in supporting people to become food citizens and to advocate for more democratic and sustainable food systems (O'Kane 2012).

Many nutrition professionals are already embracing the thinking required to champion and advocate for stronger leadership in the area of sustainable diets (and food systems). Some recognise the advancing wave of complexity-thinking which emphasises 'non-linear' contexts (Rogers et al. 2013) and promotes 'systems thinking' approaches to problem solving in food systems (Sterling 2003). Yet the complexities of this area may seem overwhelming to many nutrition professional. This new approach presents challenges for traditional ways of teaching nutrition, which are typically based on bio-medical models of 
evidence based practice and relies mainly on reductionist research paradigms (Beauman et al. 2005). Extending the remit of evidence based practice to embrace more relational models of critical thinking for transformational learning is needed in nutrition.

How nutrition professionals can pragmatically educate and advocate for the many complex sustainability issues in nutrition has already been explored by UK nutrition experts working in this area (e.g. Atherton 2016; Pettinger \& Atherton 2017; Arens 2014; Garton 2017) and some of the potential emerging opportunities for UK nutrition professionals are highlighted in Figure 1.

Students see their advocacy role as a way to promote their profession and 'to gain the trust of the nation' (Pettinger et al. 2018). Advocacy work is part of the professional graduate criteria outlined in the BDA's curriculum framework for dietitians (BDA 2013) and the argument to legally protect the 'nutritionist' title (AfN 2018). This underlines the need for students to gain confidence in a range of subject areas, including sustainability, especially as participation in nutrition advocacy in entry-level Registered Nutritionist and Dietitians can be low (Kuo et al. 2016). There is a need to ensure that (sustainability) advocacy plays a key role in training for dietitians and nutritionists and, as such, should form a key part of educational curricula (and professional CPD activities).

\section{Collaboration for advocacy of sustainability}

Within their clinical role, dietitians are accustomed to working as part of a multi-disciplinary team, including within settings outside the hospital. Nutritionists also often work with a range of partners and across different sectors. Greater impact and strengthened capacity building can be achieved through the development of a range of partnerships (Hughes and Margetts 2011). This often requires working with a clear identifiable purpose across a broad range of organisational structures and cultures (Pettinger \& Whitelaw, 2012), which can present challenges and even conflicts of interest, particularly when working with the private sector (Johnston \& Finegood 2015). Some UK dietitians and nutritionists are engaged in collaborative sustainability advocacy across a range of sectors. For example, health/wellbeing advocacy within local food partnerships, a movement that is currently being driven by the 'Sustainable Food Cities Network' (Sustainable Food Cities 2017). Other 
UK dietitians and nutritionists have been involved in leadership roles within sustainabilityrelated whole-setting approach award schemes such as 'Food for life' (Soil Association, 2017). One recommendation might be that nutrition professional bodies create the opportunity to develop, deliver (and participate in) 'sustainability-focussed' collaborative leadership programmes for their members. This aligns with leadership recommendations set out by the UK Sustainable Development Unit (PHE 2018). It also addresses the 'revitalising partnerships' element of the sustainable development goals (UN SDG 2016).

Pettinger et al. (2018) explored dietetic student views around sustainability, with one student specifying the need for closer liaison with other nutrition professionals the dietitian should work with accredited nutritionists to increase the number of and spread of the message of sustainability'. This is an interesting comment relating to the importance of collaboration between the nutrition professions to strengthen the impact of partnership working. Registered Dietitians are the only nutrition professionals with a protected title and regulated by law by the Health Care Profession Council (BDA 2013), and the UK Voluntary Register of Nutritionists (UKVRN) allows suitably trained nutrition professionals (via accredited courses) to call themselves Registered Nutritionists (AfN 2017). In the US, the professional bodies governing Nutritionists and Dietitians have combined so all are regulated together under one 'academy' (Eat Right 2018), which is a future possibility in the UK. Regardless of the current situation, barriers need to be broken down, as this presents a collaborative opportunity for all nutrition professionals to support people to combine healthy eating with sustainable eating.

\section{Policy and sustainability}

In response to a changing education, health and policy environment, the UK dietetic (and nutrition) workforces need to seek out opportunities to steer and influence local, regional and national policy (Hickson et al. 2017) and this includes influencing the sustainability agenda. Advice from dietitians and nutritionists should be based on government policies in the area, and also the policies of the communities they are working with (BDA 2013, 2017; AfN 2018). Lawrence et al. (2015) showed how important food and nutrition policy activities are to the redesign of the food system needed to promote healthy and sustainable diets. Food policies need to account for how people - citizens, communities - are affected by the 
food system problems we are seeking to address (Hawkes 2018). Recommendations within such policies include streamlining and more effective embedding of public health prevention within Allied Health Professional educational curricula. This should focus upstream on the food supply chain within a framework of policy development (Caraher \& Coveney 2004) and thus facilitate the growth of future practitioners (Kicklighter et al. 2017). Power (2005) urges that dietitians and nutritionists in all positions - not just public health or community nutrition - have a responsibility to respond to broadest issues of food systems and security by being cognizant of social policies. Lang \& Mason (2017) describe the role of nutrition professionals as being more important than ever, particularly in this ongoing period of dynamic policy flux, in achieving more sustainable food system in the UK. Dietitians and nutritionists should, therefore, be effectively trained to be proactive advocates for healthy, sustainable diets, seeking to influence a range of policy areas, including education, pricing and accessibility at a local and national level (BDA 2017).

\section{Conclusions and future directions}

Sustainability is a highly complex and fast-evolving field, and although much remains to be understood sustainable eating, its broad principles (e.g. increased intake of plant based proteins, reduced meat intake and consumption of sustainably sources fish), supported in the UK by the Eatwell Guide (PHE 2016; BDA 2017), can be communicated to the public. To translate the complex, multi-disciplinary sustainability evidence base and influence the sustainability agenda, dietitians and nutritionists need to 'amplify their visibility' (Hickson et al. 2017) consolidate their skills (Kicklighter et al. 2017) and become more sustainability literate. There is clearly a need for consensus on the definition of sustainable eating/diets, and professional standards for advocating for sustainable diets would support this development. Nutrition professionals have an important skill-set and that puts them in a strong position to be part of ongoing high level policy discussions in this area. But for this to happen, there needs to be an agreement from UK nutrition professional bodies that sustainability literacy is an essential part of educational training for their members (as is being established in the US and Canada). Curricula and professional CPD activities need to reflect this, so that the life-long learners of the nutrition professions are able to champion sustainable diets. Extending the remit of evidence appraisal within the nutrition profession to include other disciplines (e.g. climate science and political science) will support 
collaborative and transformative learning experiences. Thus substantiation of educational and professional qualifications can equip future nutrition practitioners with the skills, knowledge and aptitudes for sustainability literacy. In this manner, the nutrition professions can be better prepared for a future where many aspects of nutrition practice are likely to be affected by climate change, water and land shortage, as well as other pressing food system challenges. 


\section{$\underline{\text { References }}$}

Alles B, Peneau S, Kesse-Guyot E, et al. (2017) Food Choice motives including sustainability during purchasing are associated with a healthy dietary pattern in French adults. Nutrition Journal 16: 58

Arens U (2014) Wedding Bells? Can Nutrition Science and sustainable food policy be partners? Network Health Digest Magazine 96: 44-45

Association for Nutrition (AfN) (2018) A comparative summary of nutrition professionals available at:

www.associationfornutrition.org/Portals/0/Public/About\%20us/Nutrition\%20Professions\%2 OComparison\%20Document\%2002.2018.pdf (accessed 29.4.18)

Association for Nutrition (AfN) (2017) Competency Requirements For Registered Associate Nutritionist UK Voluntary Register of Nutritionists (UKVRN) www.associationfornutrition.org/Portals/0/Public/Registration/18122017\%20COMPETENCY \%20REQUIREMENTS\%20FOR\%20ASSOCIATE\%20NUTRITIONIST\%20REGISTRATION.pdf (accessed 1.5.18)

Association for Nutrition (AfN) (2016) Programme Accreditation Core Competence Requirements, Standards and Procedures for Undergraduate (UK levels 4-6) and taught Postgraduate (UK level 7+) education and training of Associate Nutritionists www.associationfornutrition.org/Portals/0/Public/Accreditation/AfN\%20Accreditation\%20S tandards,\%200utcomes\%20and\%20Procedures\%201st\%200ct\%202016\%20FINAL.pdf (accessed 1.5.18)

Association for Nutrition (AfN) (2018) www.associationfornutrition.org/default.aspx?tabid=71 (accessed 29.4.18)

Aston LM, Smith J \& Powles JW (2012) Impact of a reduced red and processed meat dietary pattern on disease risks and greenhouse gas emissions in the UK: a modelling study. BMJ Open2.

Atherton E (2016). Shifting towards Sustainable Diets: why dietitians should lead and influence. Dietetics Today, July 2016, 12-14.

Bajzelj B, Richards KS, Allwood JM et al. (2014) Importance of food-demand management for climate mitigation Nature Climate Change 4: 924-929

Barosh L, Friel S, Engelhardt K \& Chan L (2014). The cost of a healthy and sustainable diet who can afford it? Australian and New Zealand Journal of Public Health, 38(1), 7-12.

Beauman C, Cannon G, Elmadfa I et al. (2005) 'The Principles, Definition and Dimensions of the New Nutrition Science.' Public Health Nutrition 8: 6A, 695-98. 
British Dietetic Association (BDA) (2013) A curriculum framework for pre-registration education and training of dietitians. Available at:

www.bda.uk.com/training/practice/preregcurriculum (accessed 16.3.18)

British Dietetic Association (BDA) (2014). Dietitian, Nutritionist, Nutritional Therapist or Diet Expert? Retrieved from Birmingham:

www.bda.uk.com/publications/dietitian nutritionist.pdf

British Dietetic Association (BDA) (2017) Policy Statement - Sustainable Diets available at: www.bda.uk.com/improvinghealth/healthprofessionals/policy statement-

sustainable food (accessed 16.3.18)

BMA (2016) Obesity and Diet-Related illness in the UK. bma.org.uk. [Online] August 2016. www.bma.org.uk/-

Lmedia/files/pdfs/news\%20views\%20analysis/press\%20briefings/obesity\%20and\%20dietary \%20related\%20illness\%20in\%20the\%20uk.pdf?la=en (accessed 29.4.18).

Burlingame B \& Dernini S (2010) Division, Nutrition and Consumer Protection, \& Organisation., Food and Agriculture. (2010, Nov 3-5). Sustainable diets and biodiversity directions and solutions for policy, research and action. Paper presented at The International Scientific Symposium on Biodiversity and Sustainable Diets: United Against Hunger, Rome. http://www.fao.org/docrep/016/i3004e/i3004e.pdf

Caraher M \& Coveney J (2004). Public Health Nutrition and Food Policy. Public Health Nutrition 75: 591-98.

Carbon Trust The (2016). The Eatwell Guide: a More Sustainable Diet. 2016.

Carlsson L, Dorph JR \& Callaghan E (2017) Sustainable Food Systems that promote healthy diets: A proposed Roadmap for Dietitians of Canada. Summary of the Delphi Inquiry Process. www.dietitians.ca/Member/Get-Involved/Sustainable-Food-Systems-(SFS)-that-PromoteHealth/A-proposed-Roadmap-for-Dietitians.aspx

Clonan A, Holdsworth M, Swift et al.(2012). The dilemma of healthy eating and environmental sustainability: the case of fish. Public Health Nutrition, 15(2): 277-284

Clonan A, Wilson P, Swift JA, et al. (2015) Red and processed meat consumption and purchasing behaviours and attitudes: impacts for human health, animal welfare and environmental sustainability. Public Health Nutrition, 18(13) : 2446-2456

Cotton DRE \& Alcock I (2013) Commitment to environmental sustainability in the UK student population, Studies in Higher Education, 38:10, 1457-1471, DOI:

10.1080/03075079.2011.627423 
Council of Deans (2017) Guidance: Public Health Content within the Pre-Registration Curricula for Allied Health Professions. Council of Deans. Available via www.councilofdeans.org.uk (accessed 16.3.18)

Cross AJ, Leitzmann MF Gail MH et al. (2007) A prospective study of red and processed meat intake in relation to cancer risk. PLos Medicine, 4 (12), p. 1973

Cummins S, Smith DM, Aitken Z, et al. (2010). Neighbourhood deprivation and the price and availability of fruit and vegetables in Scotland. Journal of Human Nutrition and Dietetics, 23(5): 494-501

Darmon N \& Drewnowski A (2008). Does social class predict diet quality? American Journal of Clinical Nutrition. 87: 1107-1117

Dawe G, Jucker R \&Martin S (2005) 'Sustainable Development in Higher Education: Current Practice and Future Developments.' Report for the Higher Education Academy

DEFRA (2006) Opportunities for reducing water use in agriculture. s.I. : DEFRA, 2006.

UK Department for Environment, Food and Rural Affairs (2011). A National Statistics Publication by the Department for Environment, Food and Rural Affairs; London, UK: 2011. Family Food 2010.

Department of Health (2017) NHS Bursary Reform, Policy paper (updated on 27 Jan 2017) www.gov.uk/government/publications/nhs-bursary-reform/nhs-bursary-reform\#whychanges-to-funding-have-been-made (accessed 16.3.18)

Dibb S \& Fitzpatrick I (2014) Let's talk about meat: changing dietary behavior in the $21^{\text {st }}$ century. Eating Better www.eating-better.org/uploads/Documents/LetsTalkAboutMeat.pdf (accessed 29.4.18)

Du X, Su L \& Liu J (2013) Developing sustainability curricula using the PBL method in a Chinese context. Journal of Cleaner production 61: 80-88.

Eat Right (2018) the Academy of Nutrition and Dietetics in the United States of America www.eatrightpro.org/about-us (accessed 16.3.18)

Erikson-Weerts S (1999) Past, Present and Future Perspectives of dietetics practice. Journal of The American Dietetic Association,99, 3 p291-293

Faculty of Public Health (2010) UK Faculty of Public Health Mission, advocacy. Retrieved from www.fph.org.uk/our mission\#advocacy (accessed 16.3.18) 
Fitzpatrick I \& Young R (2017) The Hidden Cost of UK Food. The Sustainable Food Trust. Available at http://sustainablefoodtrust.org/wp-content/uploads/2013/04/HCOF-Reportonline-version-1.pdf (accessed 29.5.18)

Food and Agricultural Organisation (FAO) (2006) Livestock's Long Shadow: Environmental issues and options www.fao.org/docrep/010/a0701e/a0701e.pdf

Food and Agricultural Organisation(FAO), IFAD, WFP (2014). The State of Food Insecurity in the World 2014: Strengthening the enabling environment for Food Security and Nutrition. Rome : FAO, 2014.

Food and Agricultural Organisation(FAO), IFAD, WFP (2015). The State of Food Insecurity in the World 2014: Meeting the 2015 international hunger targets: taking stock of uneven rpogress. Strengthening the enabling environment for Food Security and Nutrition. Rome : FAO, 2015.

Food Research Collaboration (2014) http://foodresearch.org.uk/ (accessed 16.3.18)

Frey S \& Barrett J (2007) Our health, our environment: The Ecological Footprint of what we eat. Cardiff : s.n., 8-10 May 2007. International Ecological Footprint Conference

Garnett T (2014). What is a sustainable healthy diet? A discussion paper. Retrieved from Oxford:

www.fcrn.org.uk/sites/default/files/fcrn what is a sustainable healthy diet final.pdf (accessed 16.3.18)

Garton L (2016) Sustainable Eating What where and how? BDA and AfN endorsed webinar, available at: www.oatly.com/healthcareprofessionals/ (accessed 1.5.18)

Garton L (2017) Sustainable Diets Complete Nutrition, 17(6): 51-53

Gingras J, Asada Y, Fox A et al. (2014) Critical dietetics: A discussion paper. Journal of Critical Dietetics, 2(1):, pp1-12

Gonzales-Fisher C \& Garnett T (2016) Plates, pyramids and planets: developments in national healthy and sustainable dietary guidelines: a state of play assessment. Published by FAO of the United Nations \& The Food Climate Research Network at The University of Oxford

Goodman B (2011) The need for a 'sustainability curriculum' in nurse education. Nurse Education Today 31( 8): 733-737

Goodman B \& East, L (2014). The 'sustainability lens': a framework for nurse education that is 'fit for the future'. Nurse Education Today, 34, 100-103.

Goodman B, \& Richardson J (2010). Climate change, sustainability and health in UK Higher Education: the challenges for nursing. In D. S. a. S. S. P. Jones (Ed.), Sustainability Education: perspective and practice across higher education (pp. 109-131). London: Earthscan. 
Goodman M, Maye D \& Holloway L (2010). Ethical foodscapes? Premises, promises and possibilities. Environment and Planning, 42: 1782-1796.

Green R, Milner J, Dangour AD et al. (2015)

The potential to reduce greenhouse gas emissions in the UK through healthy and realistic dietary change. Climatic Change 129: 1-2, 253-265.

Harland JI, Buttriss J\& Gibson S (2012) Achieving eatwell plate recommendations: is this a route to improving both sustainability and healthy eating? Nutrition Bulletin 37 (4): 324343.

Harmon A, Lapp JL, et al.. (2011) 'Teaching Food System Sustainability in Dietetic Programs: Need, Conceptualization, and Practical Approaches.' Journal of hunger \& environmental nutrition 6, 1:114-24.

Hawkes C (2018) Let's embrace real life to drive forward real food policy change. A dispatches blog piece, City University London https://blogs.city.ac.uk/foodpolicydispatch/2018/04/30/lets-embrace-real-life-to-driveforward-real-food-policy-change/\#.WuhHKJwupkQ.twitter (accessed 1.5.18)

Hawkins, IW Balsam AL \& Graves D (2015) 'A Qualitative Study of How Registered Dietitians Made the Connection between Diet, Climate Change, and Environmental Degradation.' Journal of Hunger \& Environmental Nutrition 10 1: 47-59.

Heidelberger L, Smith C, Robinson-O'Brien et al (2017) 'Registered Dietitian Nutritionists' Perspectives on Integrating Food and Water System Issues into Professional Practice'. Journal of the Academy of Nutrition and Dietetics, 117 (2):271-277.

Hickson M, Collinson A \&Childs J (2017) Future Dietitian 2025: informing the development of a workforce strategy for dietetics. Journal of Human Nutrition and Dietetics, DOI.org/10.1111/jhn.12509

IIED \& HIVOS (2018) Advocacy Toolkit: People Centred advocacy for a more sustainable food system. Published April 2018.

Hughes R \& Margetts B (2011) Practical Public Health Nutrition. Oxford: Wiley-Blackwell.

Innes S, Shephard K, Furnari M et al(2016). Greening the curriculum to foster environmental literacy in tertiary students studying human nutrition. Journal of Hunger Environmental Nutrition. 2016:1-13. https://doi.org/10.1080/19320248. 2016.1255693.

Johnston LM \& Finegood DT (2015) Cross-sector parterships and Public Health: Challenges and Opportunities for Adressing Obesity and Noncommunicable Diseases Through Engagement with the Private Sector. Annual Review of Public Health 36: 255-271 
Kicklighter JR, Dorner B, Hunter AM et al. (2017) Visioning Report 2017: A Preferred Path Forward for the Nutrition and Dietetics Profession. Journal of the Academy of Nutrition and Dietetics, 117, 1:110-127

Kontogianni MD, Panagiotakos DB, Pitsavos C et al. (2008) CARDIO2000 case-control study European Journal of Clinical Nutrition, 62, 171-177

Kuo S, Mondelli VC, et al. (2016) Motivators and Barriers to Particiaption in Advocacy for Nutrition-related Policies among Registered Dietitian Nutritionists. Journal of the Academy of Nutrition and Dietetics, 116, 9, A87

Lang T (2018) personal communication - presentation BDA Live \#BDALive QEIl centre London, 14.3 .18 www.bda.uk.com/events/bdalive/live 2018/bda live 18 - programme (accessed 16.3.18)

Lang T (2015) Tim Lang describes the urgency behind the city food symposium. Food research collaboration http://foodresearch.org.uk/2015/page/6/ (accessed 16.3.18)

Lang T \& Barling D (2013) Nutrition and Sustainability: An Emerging Food Policy Discourse.' Proceedings of the Nutrition Society 72 1: pp. 1-12.

Lang T \& Mason P (2017) Sustainable diet policy development: implications of multi-criteria and other approaches, 2008-2017. Proceedings of the Nutrition Society, 1-16 doi:

$10.1017 / \mathrm{S} 0029665117004074$

Lawrence M, Friel S, Wingrove K et al (2015). Formulating policy activities to promote healthy and sustainable diets. Public Health Nutrition, 18(13): 2333-2340.

Macdiarmid J, Kyle J, Horgan Get al.. (2012). Sustainable diets forthe future: can we contribute to reducing greenhouse gas emissions by eating a healthy diet? American Journal of Clinical Nutrition, 96: 632-639

Marmot M (2010). Fair Society, Health Lives. A strategic Review of health Inequalities in England post-2010.

Mason P \& Lang T (2017) Sustainable Diets - welcome to the arguments. Ch1, In Sustainable Diets: How ecological Nutrition can transform consumption and the food system. Earthscan Routledge, London

Miller W (2015) UK allotments and urban food initiatives: (limited?) potential for reducing inequalities. The International Journal of Justice and Sustainability, 20 (10): 1194-1214

Millward DJ \& Garnett T (2010) Food and the planet: nutritional dilemmas of greenhouse gas emission reductions through reduced intakes of meat and dairy foods. 2010, Proceedings of the Nutrition Society, 69, 103-118. 
Ministry of Health for Brazil (2014) Dietary Guidelines for the Brazilian Population, $2^{\text {nd }}$ Edition Brasilia - DF www.foodpolitics.com/wp-content/uploads/Brazilian-DietaryGuidelines-2014.pdf (accessed 29.4.18)

National Food Agency (Sweden) (2015) Find your way to eat greener, not too much and be active. Available at: www.fao.org/3/a-az854e.pdf (accessed 29.4.18)

O'Kane G (2012). What is the real cost of our food? Implications for the environment, society and public health nutrition. Public Health Nutrition, 15(2): 268-276.

O'Kane G (2016). A moveable feast: Contemporary relational food cultures emerging from local food networks. Appetite, 105, 218-231

Orr D W (2004) Earth in mind: On education, environment, and the human prospect. Island Press, (10th Anniversary Edition)

Pettinger C, Atherton E \& Miller W (2018) Engaging student dietitians in 'sustainability principles' throughout the curriculum: an exploratory pedagogic workshop. Journal of Human Nutrition and Dietetics, 31 (suppl 1) p44

Pettinger C \& Atherton E (2017) 'Sustainable food as a health issue' Webinar delivered for Education in Nutrition, available (free) at:

https://educationinnutrition.com.au/search/c405e077afe2b6d4d99a846608ad2ef9 (accessed 16.3.87)

Pettinger C \& Whitelaw E (2012) "Food Cultures - Growing, cooking, eating: An exploration of improving food practices in young men and older adults in Plymouth." Research Evaluation Report written for local Department of Health funded project. (Unpublished), available at www.foodplymouth.org/wordpress/wp-content/uploads/2013/01/FoodCultures-FINAL.pdf (accessed 16.3.18)

Popkin BM (2002) The shift in stages of the nutrition transition in the developing world differs from past experiences! Public Health Nutrition, 5 (1A): 205-14

Power EM (2005). Individual and household food insecurity in Canada. Position of Dietitians of Canada. Canadian Journal of Dietetic Research and Practice, 66(1), 43-46.

Public Health England (2016). The Eatwell Guide. [Online] 2016. www.gov.uk/government/publications/the-eatwell-guide (accessed 16.3.18)

Public Health England (2016) National Diet and Nutrition Survey: Results from Years 5 and 6 (combined) of the Rolling Programme (2012/2013 - 2013/2014) . [Online]. www.gov.uk/government/statistics/ndns-results-from-years-5-and-6-combined.

Public Health England (2018) Sustainable Development in the Health and Care System Health Check 2018. Sustainable Development Unit. Crown Copyright, Cambridge 
QAA/HEA Education for Sustainable Development group (2014). Education for sustainable development: guidance for UK higher education providers. The Higher Education Academy

Richardson J, Grose J, et al. (2017) Developing awareness of sustainability in nursing and midwifery using a scenario-based approach: Evidence from a pre and post educational intervention study. Nurse Education Today, 54:51-55

Riley H \& Buttriss J (2011) A UK public health perspective: what is a healthy sustainable diet? Nutrition Bulletin, Vol. 36, pp. 426-431.

Robinson R \& Smith C (2003) Integrating issues of sustainably produced foods into nutrition practice: A survey of Minnesota Dietetic Association members. Journal of the Academy of Dietitians, 103, 5, 608-611

Rogers $\mathrm{KH}$, Luton $\mathrm{H}$, Biggs, R.et al (2013). Fostering complexity thinking in action research for change in social-ecological systems. Ecology and Society 18(2): 31.

http://dx.doi.org/10.5751/ES-05330-180231

Scarborough P, Allender S, Clarke D et al.(2012) Modelling the health impact of environmentally sustainable dietary scenarios in the UK. European Journal of Clinical Nutrition, 66: $710-716$.

Seed B (2015) sustainability in the Qatar national dietary guidelines, among the first to incorporate sustainability principles. Public Health Nutrition, 18(13): 2303-2310

Shephard K, Harraway J, Jowett T et al(2014) Longitudinal analysis of the environmental attitudes of university students. Environmental Education Research, 1-16.

http://doi.org/10.1080/13504622.2014.913126

Soil Association (2017) Food For Life www.foodforlife.org.uk/ (accessed 16.3.18)

Sterling S (2001)Sustainable Education - Revisioning Learning and Change. Dartington: Green Books.

Sterling S (2003) Whole systems thinking as a basis for paradigm change in education: Explorations in the context of sustainability. Ph.D. thesis, University of Bath. Retrieved from www.bath.ac.uk/cree/sterling/sterlingthesis.pdf (16.3.18)

Sterling S (2012) The Future Fit Framework: An Introductory Guide to Teaching and Learning for Sustainability in HE. The Higher Education Academy, York.

Sustainable Food Cities (2017) Network. See website http://sustainablefoodcities.org/about (accessed 16.3.18) 
Tagtow A \& Harmon AH (2009) Healthy Land, Healthy Food \& Healthy Eaters: Dietitians Cultivating Sustainable Food Systems. Available at:

www.uwyo.edu/winwyoming/pubs/healthyland\%20healthyfood\%20healthyeaters.pdf (accessed 29.4.18)

Tagtow A, Robien K, Bergquist E, et al. (2014) Academy of Nutrition and Dietetics: Standards of professional performance for Registered Dietitian Nutritionists (Competent, Proficient, and Expert) in Sustainable, Resilient, and Healthy Food and Water Systems. Journal of the Academy for Nutrition and Dietetics. 1,14 (3): 475-488

Tansey G (2015) The food system: An overview www.foodsystemsacademy.org.uk/videos/geoff-tansey.html (accessed 2.5.18)

Tilman D \& Clark M (2014) Global diets link environmental sustainability and human health. Nature, 515, 518-525

United Nations (2014) Nutrition and the Post-2015 Sustainable Development Goals: A policy Brief. United Nations System Standing Committee on Nutrition, WHO, Geneva

United Nations. SDG (2016). Transforming our world: the 2030 Agenda for Sustainable Development. Retrieved from https://sustainabledevelopment.un.org/post2015/transformingourworld (accessed 16.3.18)

UNEP Frontiers (2016) United Nations Environment Programme, Emerging issues of Environmental Concern.

https://environmentlive.unep.org/media/docs/assessments/UNEP Frontiers 2016 report emerging issues of environmental concern.pdf

UK Government (2008). Climate Change Act 2008. [Online] www.legislation.gov.uk/ukpga/2008/27/contents

Vermeulen S, Zougmore R, Wollenberg E et al(2012) Climate change, agriculture and food security: a global partnership to link research and action for low income agricultural producers and consumers Current Opinion in Environmental Sustainability, 4, 1, 128-133

Vieux F, Soler LG et al (2013). High nutritional quality is not associated with low greenhouse gas emissions in self-selected diets of French adults. American Journal of Clinical Nutrition, 97: 569-583.

Wahlqvist ML (2005). The new nutrition science: sustainability and development. Public Health Nutrition, 8(6A): 766-772.

Webb D \& Bryd-Bedbenner C (2015) Overcoming consumer Inertia to Dietary Guidance. Advanced Nutrition, 6: 391-6 
Webber, Caroline B \& Andy Sarjahani (2011) 'Fitting Sustainable Food Systems into Dietetic Internships-a Growing Trend.' Journal of Hunger \& Environmental Nutrition 6 4, pp. 47789.

Wegener J (2018) Equipping Future Generations of Registered Dietitian Nutritionists and Public Health Nutritionists: A commentary on Education and Training needs to Promote Sustainable Food Systems and Practices in the $21^{\text {st }}$ Century. Journal of the Academy of Nutrition and Dietetics. 118(3): 393-398

WilkinsJL, Lapp J et al. (2010). 'Beyond Eating Right: The Emergence of Civic Dietetics to Foster Health and Sustainability through Food System Change.' Journal of Hunger \& Environmental Nutrition 5 1: pp. 2-12.

Winter J, Cotton D et al. (2015) 'The University as a Site for Transformation around Sustainability.' International Journal of Innovation and Sustainable Development 9 3-4 (2015): pp. 303-20. 